Ann. Génét. Sél. anim., I978, 10 (4), 525-531.

\title{
Sex-linked Dwarf gene and chick survival to acute Hypoxia
}

\author{
P. MÉRAT $\left({ }^{*}\right)$, M. STUPFEL $\left({ }^{* *}\right)$, G. COQUERELLE $(*)$ et A. PERRAMON(*) \\ (*) Labovatoive de Génétique factorielle, \\ Centre national de Recherches zootechniques, I.N.R.A., \\ 78350 Jouy-en-Josas \\ ** Groupe de Recherches sur les nuisances de l'environnement, INSERM, 781 Io Le Vésinet
}

\section{Summary}

Two experiments with acute hypoxia were performed (in 1977 and 1978) on 4 week old chicks. Two genotypes were compared as concerns the $d w$ sex linked gene : " normals" (Dw + $d w$ for males, $D \varkappa^{+}$for females). vs "dwarfs" ( $d w d w$ for males, $d w$ for females). Chicks of both genotypes were progeny of the same parents. The $d w$ gene was found associated in every case with considerably better survival to hypoxia. The size reduction caused by this gene can only very partly account for this effect.

\section{Introduction}

Differences between families, with a likely genetic origin, were found in the Japanese quail for survival to acute hypoxia at 4 weeks (PERRAMON et al., I976).

A recessive sex-linked "dwarf" gene reducing body size is known in the domestic fowl (HUT'T, I959). Results reviewed by GUILLAUME (I976) show among other things that it is associated with a moderate hypothyroidism and reduction of basal metabolism.

It thus seemed interesting to compare resistance to acute hypoxia of chicks of different genotype at the Dw locus. A first result was briefly reported (STUPFEI, et al., I978). More complete and detailed results are presented here. At the same time differences between families were examined, along with the effect of individual body weight.

\section{Material and methods}

Two experiments were carried out, on chicks of both sexes aged of 4 weeks, hatched respectively on I6-II-I977 and 25-ro-I978.

These chicks were issued from a population bred at the Laboratoire de géné- 
tique factorielle, I.N.R.A. They came from a cross between males heterozygous for the alleles $D w^{+}$(" normal " size) and $d w$ (" dwarf ") and hemizygous $d w$ females. $D w^{+}$was linked with the dominant $S$ allele (" silver" down and plumage) and $d w$ was linked with the $s$ recessive (" gold " down). So the genotype at the Dw locus was marked by down color at hatching and later by plumage color, with an expected percentage error corresponding to recombination rate between the $\mathrm{D} w$ and $\mathrm{S}$ loci, close to 8 per cent (E,TChes and HAwEs, I973; Somes, I973). Genotypes compared among progeny were, for males, $D w+d w$ and $d w d w$, and for females $D w^{+}$ and $d w$, the first genotype in each sex corresponding to the " normal size " phenotype, the second corresponding to the "dwarf" phenotype. All clicks hatched were pedigree and wingbanded. I38 chicks were tested for hypoxia in 1977; they came from four sires of a "heavy" subgroup of our population. In 1978 , the 225 chicks tested came from eight sires of another substrain with slower growth rate. Sex was determined by cloacal examination at batching. Chicks were reared on floor (Laboratoire de Génétique Factorielle) with feed given ad libitum as mash; temperature under brooders was $35^{\circ} \mathrm{C}$ at day old age and decreased gradually to $20-22{ }^{\circ} \mathrm{C}$ at four weeks of age. Birds were then weighed, transferred to INSERM I23 Unit and kept in cages at $20-2 \mathrm{I}{ }^{\circ} \mathrm{C}$ and 60 per cent relative humidity in a room with LDI2 I2 lighting regimen until the hypoxic challenge. Obtention of hypoxia by nitrogen flux within a hermetic chamber was previously described (PERRAmon et al., I976; STUPFEL et al., I978). Each test was carried out on an approximately equal number of chicks of the two genotypes within each sex. The test was stopped when about half of the birds were dead. Comparison of mortality rates by genotype and sex was done by a contingency chi-square, as well as comparison between sire families. As regards 4 weeks body weight, mean values of survivors and dead chicks were compared by $t$-tests within homogeneous subgroups. Finally, to evaluate whether there are any effects on resistance to hypoxia associated with the $d w$ gene and independent of body weight, homogeneity of survival rate was tested between genotypes (contingency chi-square) within the same body weight classes.

\section{Results}

Table I shows survival rate to hypoxia for each experiment by genotype and sex, then by sex with genotypes being pooled, and by genotype with sexes pooled. Chi-square values are given for each comparison between genotypes. The validity of groupings will be discussed later.

Table $z$ gives chi-square values corresponding to homogeneity tests between sire families for survival rate, separately for " normals" and for "dwarfs", sexes pooled.

With regard to 4 weeks body weight, table 3 gives the difference between mean values of surviving versus dead chicks within each year-sex-genotype subgroup.

Table 4 contains numbers of survivors and dead chicks of both sexes pooled, within each body weight class, for " normal" chicks compared to " dwarfs". Corresponding homogeneity chi-squares between genotypes within classes are presented. The number of body weight classes was restricted so as to obtain sufficient numbers within classes. 
SEX LINKED DWARF GENE AND HYPOXIA

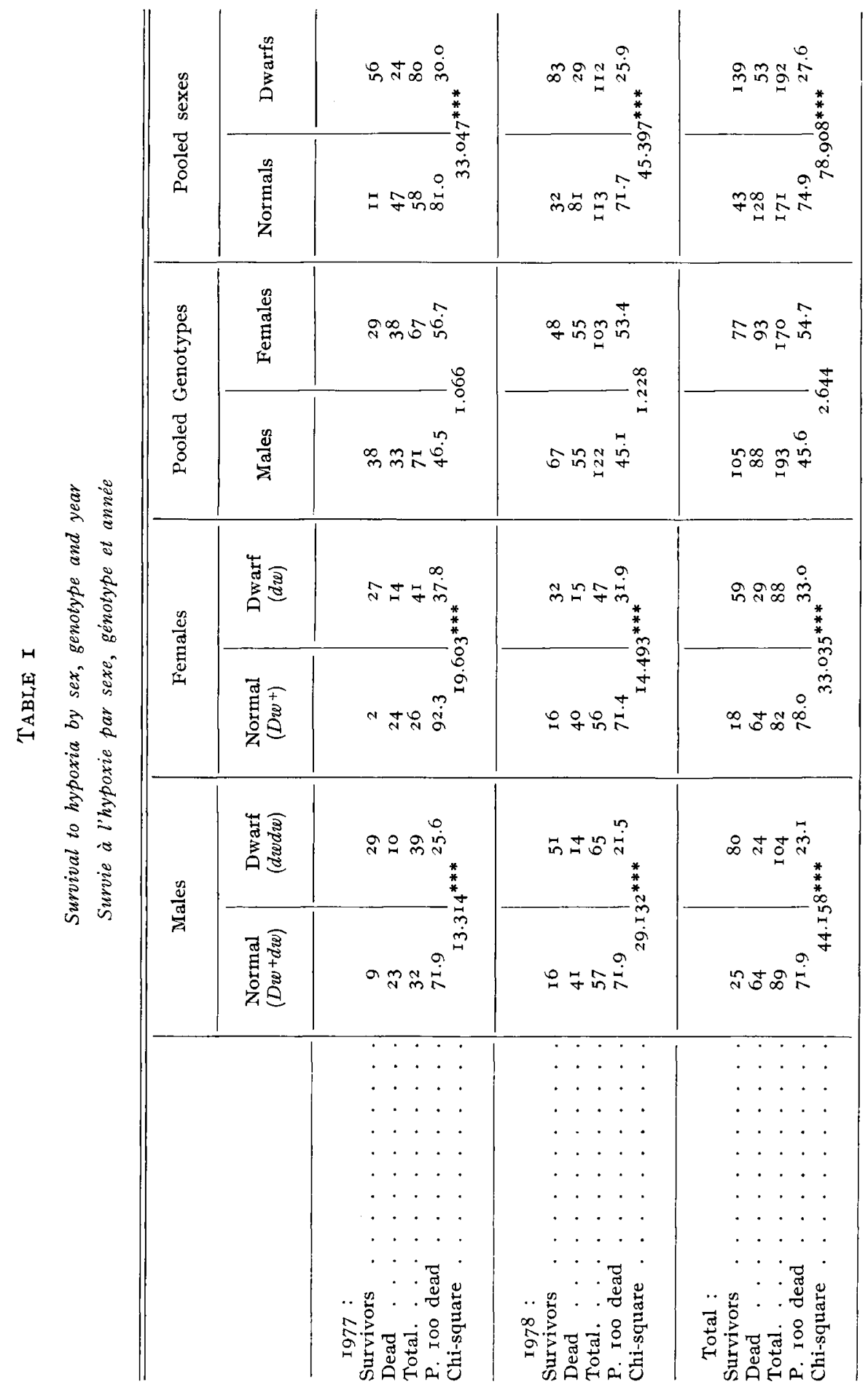

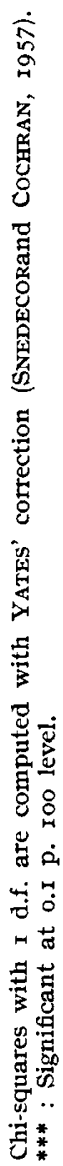


TABLE 2

Test of homogeneity of survival rate to hypoxia between sire families, for " normal" and "dwarf" chicks

Test d'homogénéité du taux de survie à l'hypoxie entre familles de pères, pour les poussins " normaux " et "nains"

\begin{tabular}{|c|c|c|c|c|c|c|}
\hline \multirow{2}{*}{ Year } & \multicolumn{3}{|c|}{ "Normals" } & \multicolumn{3}{|c|}{ "Dwarfs " } \\
\hline & d.f. & Chi-square & Significance & d.f. & Chi-square & Significance \\
\hline $\begin{array}{lllll}\mathbf{1 9 7 7} & . & . & . & . \\
1978 & . & . & . & .\end{array}$ & $\begin{array}{l}3 \\
7\end{array}$ & $\begin{array}{r}2.526 \\
13.605\end{array}$ & $\begin{array}{c}\text { N.S. } \\
\text { N.S. } \\
(\mathrm{P}<\text { o.Io })\end{array}$ & $\begin{array}{l}3 \\
7\end{array}$ & $\begin{array}{l}\mathrm{r} .770 \\
7.078\end{array}$ & $\begin{array}{l}\text { N.S. } \\
\text { N.S. }\end{array}$ \\
\hline
\end{tabular}

\section{TABLE 3}

Mean 4-week body weight for survivor vs dead chicks by year, sex and genotype(1) Poids moyen à 4 semaines pour les poussins survivants et morts par année, sexe et génotype

\begin{tabular}{|c|c|c|c|c|c|c|c|c|}
\hline & \multicolumn{4}{|c|}{ Males } & \multicolumn{4}{|c|}{ Females } \\
\hline & \multicolumn{2}{|c|}{ Normal } & \multicolumn{2}{|c|}{ Dwarf } & \multicolumn{2}{|c|}{ Normal } & \multicolumn{2}{|c|}{ Dwarf } \\
\hline$\cdot$ & $n$ & $\begin{array}{l}\text { Mean } \\
\text { weight } \\
\text { (g) }\end{array}$ & $n$ & $\begin{array}{l}\text { Mean } \\
\text { weight } \\
(\mathrm{g})\end{array}$ & $n$ & $\begin{array}{l}\text { Mean } \\
\text { weight } \\
\text { (g) }\end{array}$ & $n$ & $\begin{array}{l}\text { Mean } \\
\text { weight } \\
\text { (g) }\end{array}$ \\
\hline $\begin{array}{l}\text { I977: } \\
\text { Survivors . } \\
\text { Dead . . . } \\
\text { Difference. }\end{array}$ & $\begin{array}{r}9 \\
22\end{array}$ & $\begin{array}{r}314.0 \\
347.0 \\
-\quad 33.0 \\
\end{array}$ & $\begin{array}{l}25 \\
10\end{array}$ & $\begin{array}{r}284.8 \\
324.4 \\
-\quad 39.6 \\
\end{array}$ & $\begin{array}{r}2 \\
23\end{array}$ & $\begin{array}{r}271.0 \\
344.6 \\
-\quad 73.6 \\
\end{array}$ & $\begin{array}{l}27 \\
\mathbf{1} 4\end{array}$ & $\begin{aligned} & 274.6 \\
& 296.1 \\
&- 21.5 \\
&\end{aligned}$ \\
\hline $\begin{array}{l}\text { I978: } \\
\text { Survivors . } \\
\text { Dead . . } \\
\text { Difference. }\end{array}$ & $\begin{array}{l}\text { I } 6 \\
4 \text { I }\end{array}$ & $\begin{array}{r}274.4 \\
263.7 \\
+\quad 10.7\end{array}$ & $\begin{array}{l}50 \\
\text { I } 3\end{array}$ & $\begin{array}{r}224.6 \\
254.6 \\
-\quad 30.0\end{array}$ & $\begin{array}{l}\text { I6 } \\
37\end{array}$ & $\begin{array}{r}253.1 \\
259.5 \\
-\quad 6.4\end{array}$ & $\begin{array}{l}32 \\
15\end{array}$ & $\begin{array}{r}\text { I } 95.9 \\
\text { I } 89.4 \\
+\quad 6.5\end{array}$ \\
\hline
\end{tabular}

(1) A few birds included in the survival test were not weighed.

\section{Discussion}

Table I shows an overall superiority of "dwarf" birds as compared to " normals" for survival to acute hypoxia. Results, on the whole and within subgroups, are very similar for the two years. For " normal " chicks, "dwarf" chicks and all birds together, with pooled sexes, the between years homogeneity 
TABLE 4

Survival to hypoxia within body weight classes for " normal" vs. " dwarf" birds Survie à l'hypoxie à l'intérieur des mêmes classes de poids pour les poussıns "normaux " et "nains"

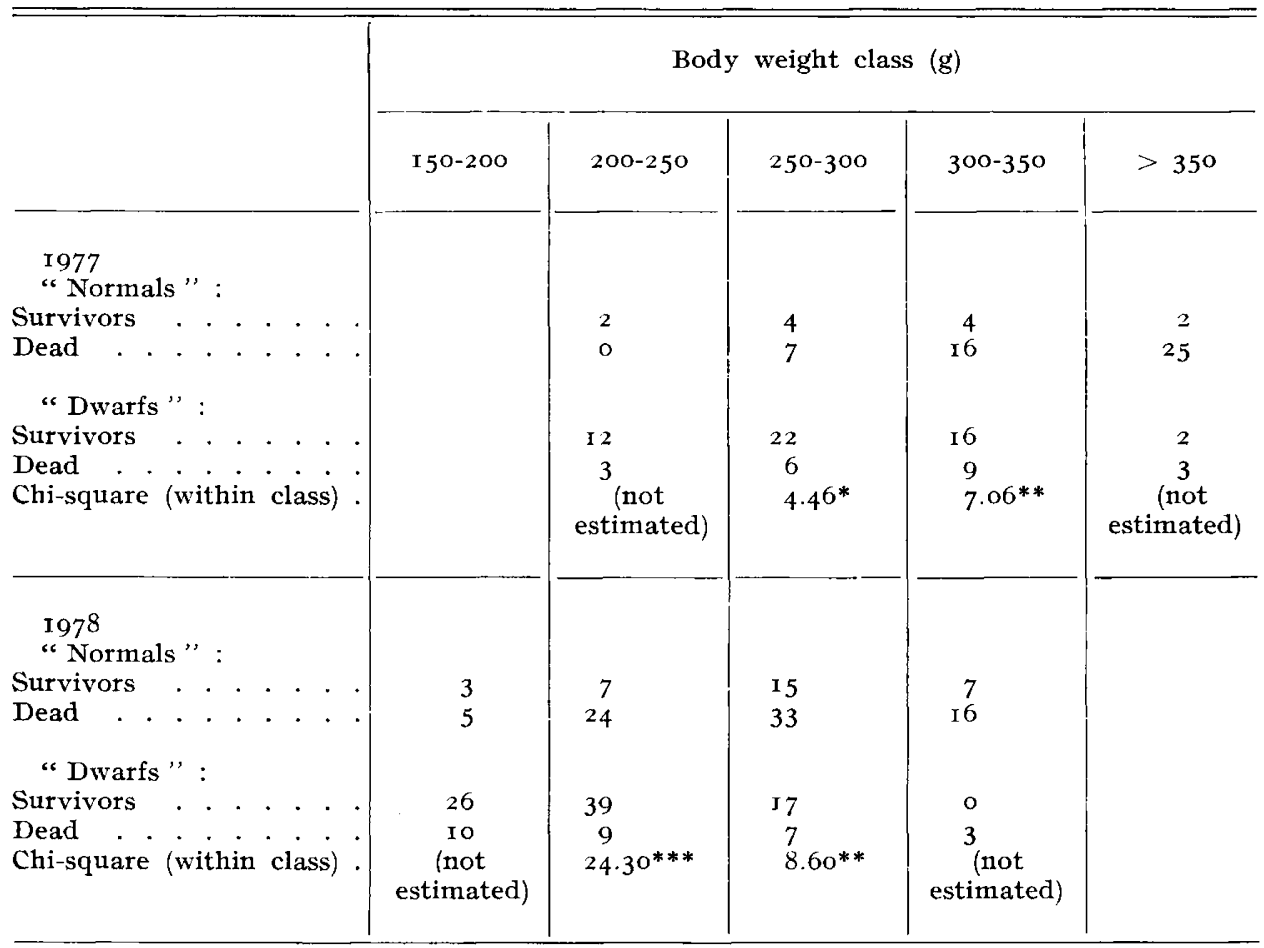

*, **, *** : Significant respectively at 5 p. roo, I p. roo, and o.I p. roo level.

chi-square value is respectively I.3I5, 0.2I6 and 0.290 for I d. f. (unsignificant values).

On the other hand, in spite of the fact that for each year mortality is slightly less among males than among females, the sex difference, on the whole, does not reach the significance level $(\mathrm{P}>$ o.ro).

Accordingly, it seems appropriate to pool both years and sexes in comparing mortality rate of " normal " and "dwarf " chicks. The chi-square value obtained in this way corresponds to a probability which is largely inferior to 0.001 . Values obtained within each sex give the same conclusion.

For sire families, no significant heterogeneity appears between them (table 2). This results differs from that obtained in a population of Japanese quails (PERRAMON et al., I976), possibly due to the limited sample of families used here.

Data on 4-week body weight (table 3) show, incidentally, a relatively low sexual dimorphism on the whole, although it is somewhat higher among dwarf birds: the average weight of dwarf females is $92.0 \mathrm{p}$. Ioo of that of males, and 97.4 p. Ioo for " normals". As expected (HuTr, I949) the effect of the $d w$ gene 
on growth rate is already apparent at 4 weeks: " dwarf ,, birds on average weigh $87.3 \mathrm{p}$. IOC as much as " normals" for males, and $82.5 \mathrm{p}$. Ioo for females. On the other hand, the conspicuous mean difference between years may be explained wholly or partly by the different parental origins.

Concerning the relationship between body weight at 4 weeks and survival to hypoxia, in 1977 survivor on average are lighter than dead birds in all subgroups. Pooling sexes (which in this case do not show a significant difference in weight), the comparison of survivors and dead respectively among "normals " and "dwarfs", give $t$ values of $2.97(\mathrm{P}<0.0 \mathrm{I})$ and $2.3 \mathrm{I}(\mathrm{P}<0.05)$. However, in $\mathrm{I} 978$ the mean body weight of survivors and dead chicks only differs significantly in the same direction among "dwarf" males $(t=2.60, \mathrm{P}<0.0 \mathrm{I})$, other differences being of variable direction and non-significant.

Comparatively speaking, the difference in survival rate between " normal " and "dwarfs" appears at first sight to be too large to be entirely explained by the effect of the $d w$ gene on body weight. This may be tested by comparing mortality of the two genotypes at the $\mathrm{D} w$ locus within the same body weight classes (neglecting a possible but anyway small difference in weight distribution for " normals" and "dwarfs" within each class). Table 4 in fact shows that the difference in mortality rate remains significant or highly significant within all classes where numbers of birds are sufficient for estimating a contingency chi-square. It must be added that possible recombinations between $d w$ and the color " marker " gene $S$ will lead to underestimate the differences at the $D w$ locus, as they will make the observed difference (evaluated from the $S / s$ segregation) lower than the real one.

To conclude, the $d w$ sex-linked dwarf gene is associated with a consideratly better resistance to short-term acute hypoxia. As the effect of the $d w$ gene can only partly be accounted for by its influence on body weight, it remains to be determined which physiological cause can be invoked. It is open to question, in particular, whether the limited depression in basal metabolism found associated with $d w$ (GUILLAUME I976) may be a sufficient explanation for the large effect of this gene on hypoxic survival.

Reçu pour publication en février 1979.

\section{Acknowledgements}

We thank $\mathrm{D}^{\mathrm{r}}$ SELLIER (Département de Génétique animale, I.N.R.A. Jouy-en-Josas) for his useful suggestions in presenting this paper.

\section{Résumé}

\section{Gène de nanisme lié au sexe et survie des poussins à une hypoxie aiguë}

Deux expériences sucessives avec hypoxie aiguë ont été réalisées (en I977 et I978) sur des poulets de 4 sèmaines d'âge issus des mêmes parents. Deux génotyues étaient comparés, concernant le locus $D w$ lié au sexe : "normaux " (mâles $D w^{+} d w$, femelles $D w^{+}$) et "nains " (mâles $d w d w$, femelles $d w$ ). Le gène $d w$ était dans tous les cas associé à une survie considérablement meilleure à l'hypoxie : ceci ne peut s'expliquer uniquement par la réduction de taille qu'il apporte. 


\section{References}

EiTCHES A. J., HAwES R. O., I973. A summary of Linkage relationships and a revised Linkage map of the chicken. Can. J. Genet. Cytol., 15, 553-570.

Gurllaume J., r969. Conséquences de l'introduction du gène de nanisme dw sur l'utilisation alimentaire chez le poussin femelle. Ann. Biol. Anim. Bioch. Biophys., 9, 369-378.

GUillaume J., I976. The dwarfing gene dw: Its effects on anatomy, physiology, nutrition, management. Its application in poultry industry. World's Poult. Sci. J., 32, 285-304.

HutT F. B., I959. Sex-linked dwarfism in the fowl. J. Heved., 50, 209-22I.

Perramon A., Merat P., Stupfei, M., Moutet J. P., Magnier M., i976. Mise en évidence, chez la caille japonaise, de différences génétiques lors de la survie à l'hypoxie. C.R. Acad. Sci. Paris, sér. D, 283, I3І3-г315.

SNEDECOR G. W., Cochran W. G., 1957. Statistical methods, 6th ed. Iowa State University Press.

SOMES R. G., I973. Iinkage relationships in domestic fowl. J. Heved., 64, 21 7-22 I.

Stupfel M., Merat P., Perramon A., Masse H., Pletan Y., i978. Resistance à 1'hypoxie expérimentale de divers phénotypes de souris, de rats et de poulets. J. Physiol. (in press).

Stupfer M., Perramon A., Gasc. J. M., Magnier M., Duriez M., 1978. Body dimorphism and Sex difference of resistance to an acute hypoxic challenge in rodents and birds of different ages. Comp. Biochem. Physiol., 59A, 347-354. 